\title{
Simulation and economic analysis of solar cooling for building in tropical climate of Surabaya, Indonesia
}

\author{
Elieser Tarigan ${ }^{1, *}$ \\ ${ }^{1}$ Electrical Engineering Department and PSET, Faculty of Engineering, University of Surabaya \\ Jalan Raya Kalirungkut, Surabaya, Indonesia
}

\begin{abstract}
The possibility of solar cooling technologies is simulated and discussed in this work. Cooling system application for a six-floor university building in Surabaya Indonesia was taken as a case study. Two different solar technologies systems were designed and compared: (i) photovoltaic powered cooling system, and (ii) solar thermal absorption cooling system. Economic analysis was carried out based on the economic key-figures as well as the $\mathrm{CO}_{2}$ emission analysis. Based on the results gained in the profitability analysis, the most economically feasible system is solar thermal absorption cooling system due to the good agreement between solar radiation and cooling demand. Besides, this systems allows the maximum $\mathrm{CO}_{2}$ emissions savings.
\end{abstract}

\section{Introduction}

Air conditioning for hot climate conditions is a growing market due to increased thermal loads, as well as improving living standards. There are now different cooling technologies available on the market used to provide temperature and humidity control on premises. The most popular conditioning systems use the compressor cycle in order to gather the surplus heat from indoors and release it outdoors. The refrigerant is a working fluid used to absorb, transport and release heat. The whole process is driven by electricity. Absorption chillers are regaining popularity because of the possibility that they offer to use residual thermal energy in combined heat and power applications. Moreover, they can be successfully applied in solar cooling systems [1].

Solar cooling technology, especially in hot climates, has huge energy-saving potential in comparison to conventional technologies. A number of studies have been carried out on this topic. A solar absorption cooling system was simulated in TRNSYS for Spanish weather conditions by Cassals, 2006 [2]. Ali et al., (2008) [3] reported that in 2002, an integrated free cooling and solar-powered single-effect lithium bromide-water absorption chiller was built in Oberhausen, Germany. The free cooling percentage was evaluated to be up to $70 \%$, and it covered $25 \%$ of the total cooling demand during its five years in operation. The monthly average solar fraction was calculated at between $31.1 \%$ and $100 \%$. According to

\footnotetext{
* Corresponding author: elieser@staff.ubaya.ac.id
} 
the calculations performed in work under discussion, the specific collector must be 4.23 $\mathrm{m}^{2} / \mathrm{kW}$ cold to harvest the maximum possible solar heat fraction.

The potential for extending the usability of solar systems not only to cooling buildings but also to heating them in the cold months was evaluated [4]. The study showed that the most feasible uses of integrated solar cooling and heating systems are for residential houses and office buildings. The reasonable payback time can be achieved only for Southern European locations (e.g., Rome). Therefore, in order to make such technology more competitive, the prices for solar collectors and absorption chillers must be reduced.

In present work, two different possibilities of solar cooling technologies are simulated using Polysun software each for: (i) photovoltaic powered cooling system, and (ii) solar thermal absorption cooling system. Taking into account the high level of daily average solar radiation and the number of peak sun hours during the year the two technical solutions were considered have a good potential. The objective of the study is to find the most effective solar based technological solution for a cooling system for a building under tropical, climate of Surabaya, Indonesia. Economic analysis was carried out based on the economic key-figures as well as the $\mathrm{CO}_{2}$ emission analysis.

\section{Methods}

\subsection{Simulated building characteristics}

The object of the present study is an existing six-floor library building at the University of Surabaya, Indonesia. The building measures $10,625 \mathrm{~m} 2$ in total. The front of the building faces South West. The front and top views, taken from Google Earth ${ }^{\mathrm{TM}}$ [5] of the building are shown in Figure 1.
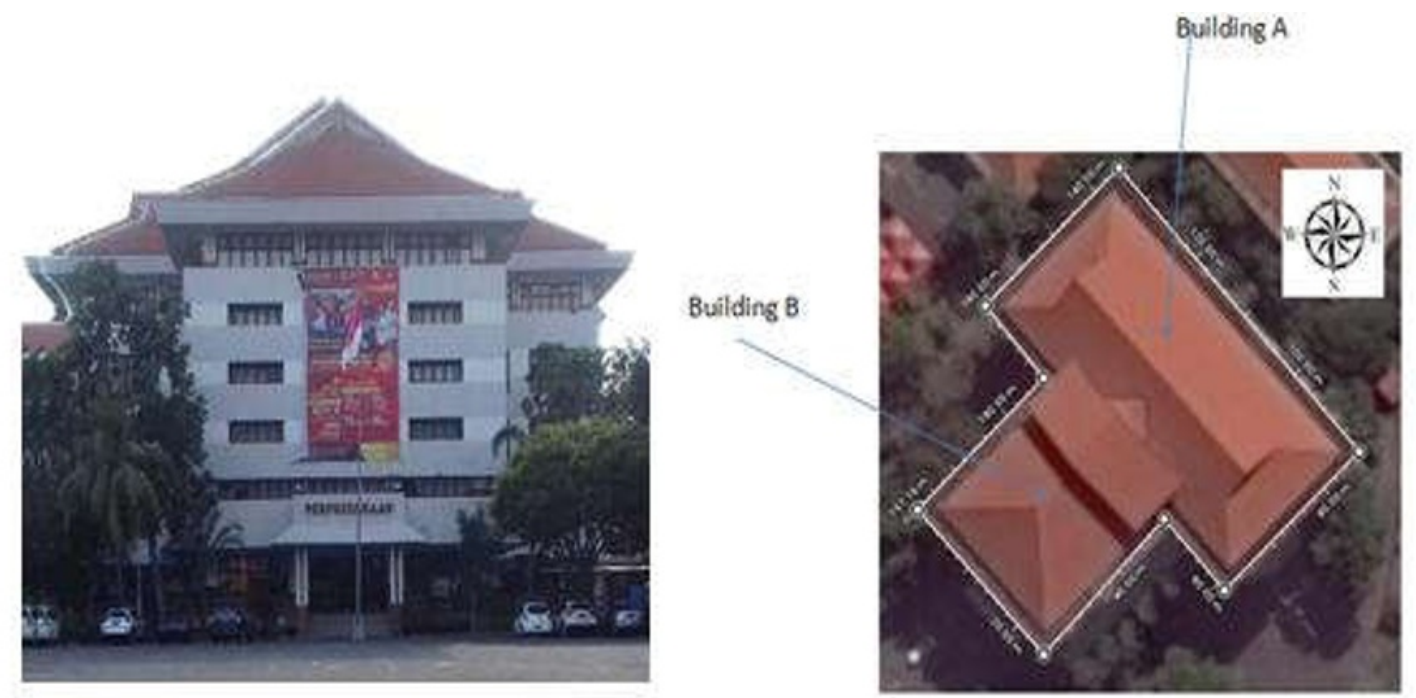

Fig. 1. Front and top view of the simulated building

The building consists of two parts namely building A and building B. Inside of the building some stairs connecting the floors and building A and B. Outside of the building consist of:

-terrace wall which is widely open

-terrace with $2.5 \mathrm{~m}$ width, around the building for each floor.

-main wall of the building with window-to-wall ratio (WWR) of $30 \%$ 
The wall is constructed by common brick and plaster (inside), and plaster + ceramic (outside), so that the total thickness of the wall is about $160 \mathrm{~mm}$. The floor is from of 20 $\mathrm{cm} \times 20 \mathrm{~cm}$ ceramic. About $30 \%$ of façade and all sides of the exterior wall are closed windows glass of single layer with aluminum frame. Inside of the building is divided into several partitions for different purposes, such as bookshelves, reading rooms, computer rooms, offices, bathrooms, etc.

\subsection{Cooling Load}

When the building was constructed, the cooling system was designed with the capacity that it would supply cooling for the whole building. The system consists of 6 chillers /and compressors, each $57.42 \mathrm{~kW}$, so in total $57.42 \mathrm{~kW}$ x $6=344.52 \mathrm{~kW}$ (electricity power). The number of power is approximately the same when it is calculated based on so-called "rule of thumb" AC sizing in Indonesia [6]

$$
\mathrm{P}=(\mathrm{L} \times \mathrm{W} \times \mathrm{H} \times \text { Factor1 } \mathrm{x} 37)+(\text { Poeple } \mathrm{x} \text { Factor2 })[\mathrm{BTU}]
$$

where: $\mathrm{W}=$ width of the room $(\mathrm{m}), \mathrm{L}=$ length of the room $(\mathrm{m}), \mathrm{H}=$ height of the room $(\mathrm{m})$, and People $=$ number of people in the room. Factor 1 corresponds to: bad room $=5$, office and living room $=6$, and restaurant, salon or mini market $=7$. Factor 2 corresponds to: adult $=600$, and Child $=300$. For the library in this study, the number of adults is assumed about 300 people.

\subsection{Simulation}

To simulate the system and for optimal design configuration, the simulation software Polysun is used. The software allows for dynamic simulation of the energy systems. The simulation was designed based on the given boundary conditions (Indonesian climate data and cooling demand) [7]. The cooling load was calculated based on the rule of thumb formulae applicable to this particular building type in Indonesia, i.e $344 \mathrm{~kW}$. The cooling systems were compared based on energy and economic criteria. For the economic calculations, the embedded Polysun model is used. Based on the comparative analysis, the optimal solution is recommended. Two different solar technologies systems were simulated, each for: (i) photovoltaic powered cooling system, and (ii) solar thermal absorption cooling system.

\section{Results and Discussion}

\subsection{PV powered air conditioning}

The main idea of this system is to improve and enlarge the existing conditioning system so that it covers demand since according to data provided, the existing system is currently insufficient to cover the demand. Moreover, the photovoltaic system can be built using the resources saved from the existing facilities. This option is also economically reasonable because the cooling demand coincides with the time that solar energy is generated. The main components systems are PV panel and inverter with the configuration is as shown in Figure 2. 


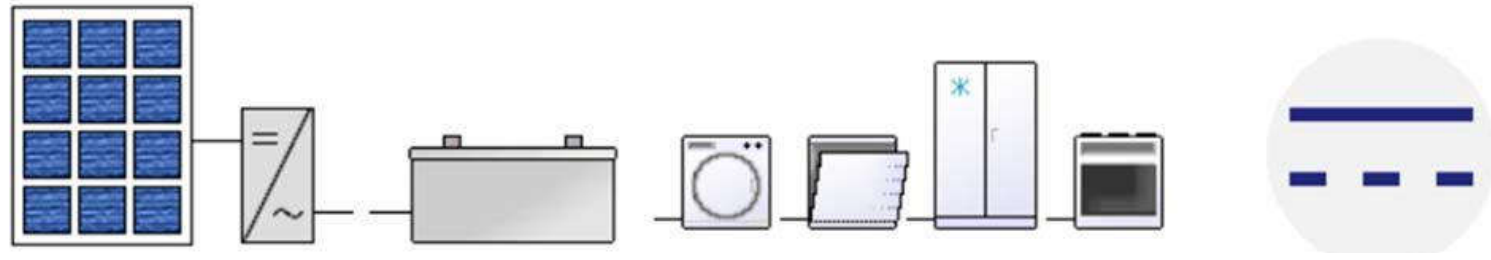

Fig. 2. The air conditioning system powered by PV system(generated from Polysun simulation software)

Simulation results show that about $376 \mathrm{kWp}$ of PV panels required to full fill energy for cooling load. For the installation of the solar panel, the following layouts were considered: The library building roof was used for the photovoltaic field. However, due to the big load, the roof area is not enough to cover the electricity demand, and thus the second variant for the layout of the PV modules was considered. The PV modules are placed on the roof of the parking lot in front of the library. Of course, the main condition for this layout is the building of the carport. Another advantage of the carport is preventing cars from overheating in the sun.

\subsection{Absorption Chiller With Solar Collectors}

The screenshot of the system is shown in Figure 3. In the system, the collector system is used as the main energy generation. While the gas boiler covers peak loads and provides a backup auxiliary energy source (it covers periods during which solar radiation is not sufficient, such as cloudy days or mornings when the charge in the water storage is not

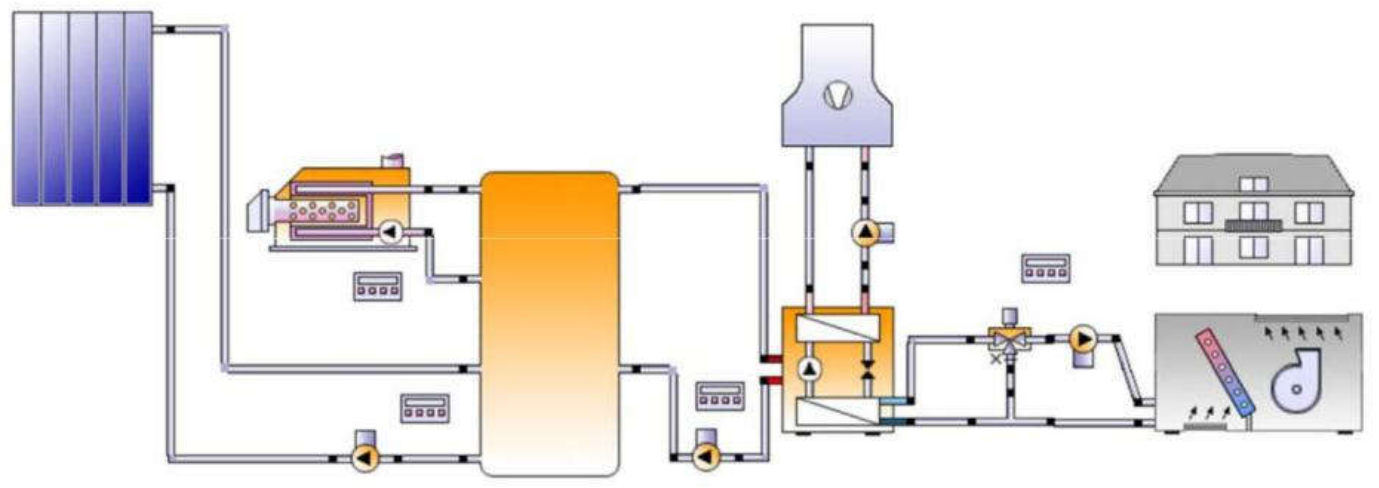

Fig. 3. Absorption chiller as a cooling technology and solar collectors as the primary heat generator (generated from Polysun simulation software)

enough). The main system components are: an absorption chiller (300 kW cooling capacity), a 1600 flat-plate premium solar collector, a gas boiler for auxiliary heat generation (capacity $200 \mathrm{~kW}$ ), a storage tank (400,000 1) and a cooling tower for the condensation of working fluid in the chiller using ambient air.

The main aim of this system is to show the possibility of utilizing solar thermal energy in the cooling system based on the absorption cooling machine. In the system under discussion, standard flat/plate collectors can be used because the temperature in the chiller generator is not very high. This system was not optimized as it was only used to provide an example of how this particular technology might be used. There is room for improvement 
by using different types of the collector (vacuum-tube or concentrated), different solar fractions, different storage systems (tank-in-tank storage system, borehole storage or pit thermal energy storage) and different system configurations. The advantage of this system is the same as the photovoltaic system, in that the cooling demand occurs simultaneously with solar energy supply. Therefore, there is a possibility of using a smaller boiler, and only for the periods during which the capacity of the solar collector field is not sufficient. It is important to note that for any further work with this variant, attention must be paid to the stagnation in the solar collector field, and the necessary means for preventing such stagnation must be provided in the design project.

\subsection{Economic Feasibility Analysis}

The profitability tool embedded in the Polysun software as well as excel-calculator were used for these calculations. There were almost no economic data available from the site, therefore assumptions have to be met in order to calculate the profitability of the projects. With more accurate prices available, the feasibility of the project can be recalculated using the Polysun profitability calculations or excel calculator.

In order to compare different systems, the following key-figures have been chosen: investment costs, net-present value, annuity, renewable energy fraction and $\mathrm{CO} 2$ savings. The results of the comparison is shown in Table 1 . The capital recovery factor (CRF) was taken 0.0546 for both systems i.e., by assuming that the real discount rate of $5 \%$ and number of annuities received of 40 year [1].

Table 1. Key figures comparison of solar cooling systems

\begin{tabular}{|l|l|c|}
\hline \multicolumn{1}{|c|}{ Key Figures } & $\begin{array}{c}\text { PV Powered } \\
\text { Cooling System }\end{array}$ & $\begin{array}{c}\text { Solar Thermal } \\
\text { Cooling System }\end{array}$ \\
\hline Investment Costs [USD] & $14,759,567$ & 783,996 \\
\hline NPV & $-2,987,924$ & $-434,986$ \\
\hline Annuity & 163,068 & 23,740 \\
\hline Renewable Energy Fraction [\%] & 100 & 100 \\
\hline CO2 Savings [kg]/Year & 271,390 & 487,498 \\
\hline
\end{tabular}

It obviously seen that the investment cost for solar PV powered cooling system almost double of the solar thermal cooling system. This system has been designed based on the assumption that the available air condition system remains the same and operates well. However, it is worth to mention, that the installed capacity of the current system corresponds to the required capacity calculated with the rule of thumb for this type of buildings in Indonesia, and yet the set temperature is not met, and premises are heating up to 35 degrees during the day. Therefore, the technical evaluation and maintenance, possibly replacement with the new one have to be considered. In this case, the costs of maintenance, repairs or replacement have to be added.

The lower annuity was found for the solar thermal cooling system, which operates $100 \%$ on the solar thermal energy means there is no need to pay for electricity/gas consumption. Moreover, this system has the high rate of CO2 savings of 487,498 [kg] annually. The biggest drawback of the proposed system is the area needed to install the solar collector field. The negative NPV shows that the earnings generated from the investment did not exceed the anticipated costs. However, NPV does not consider the usevalue of the air conditioning system for the library in the cash-flows. The advantage of increasing the quality of service provided by the library cannot be measured as a direct financial return. Indonesia is now striving to reform the subsidy policy on the electricity 
market in order to reduce the level of using coal for electricity generation and thus the level of GHG emissions. The removal of subsidies gives an opportunity to invest into the clean energy sources.

\section{Conclusions}

The simulation and economic analysis of solar cooling for building in tropical climates in Surabaya, Indonesia has been carried out. Two different possibilities of solar cooling technologies are simulated using Polysun software each for: (i) photovoltaic (PV) powered cooling system, and (ii) solar thermal absorption cooling system. For the PV powered option, about $376 \mathrm{kWp}$ of PV panels required to full fill energy for cooling load. While for solar thermal absorption cooling system option, the main system components are: an absorption chiller (300 kW cooling capacity), a $1600 \mathrm{~m} 2$ flat-plate premium solar collector, a gas boiler for auxiliary heat generation (capacity $200 \mathrm{~kW}$ ), a storage tank $(400,0001)$ and a cooling tower for the condensation of working fluid in the chiller using ambient air. From economic aspect, the investment cost for solar PV powered cooling system almost double of solar thermal cooling system, means that solar thermal absorption cooling system is more feasible than PV. This is due to the good agreement between solar radiation, efficiency, and cooling demand. Besides, this systems allows the maximum $\mathrm{CO} 2$ emissions savings.

\section{References}

1. Hanna Satnikova (2017), Solar cooling system for the university library in Surabaya, Indonesia. semester Project Report, ZHAW School of Engineering.

2. Casals, X. G. (2006). Solar absorption cooling in Spain, Perspectives and outcomes from the simulation of recent installations. Renewable Energy, 1371-1389

3. Ali H. , A. H., Noeres, P., \& Pollerberg, C. (2008). Performance assessment of an integrated free cooling and solar powered single-effect lithium bromide-water absorption chiller. Solar Energy, 1021-1030.

4. Mateus, T., \& Oliveira, A. C. (2009). Energy and economic analysis of an integrated solar absorption cooling and heating system in different building types and climates. Applied Energy, S. 949-957.

5. https://www.google.com/maps

6. Nationalelektronik.com (2017), Cara menghitung kebutuhan pemakaian PK AC sesuai ruangan. Access 19-02-2017. https://www.nationalelektronik.com/2017/01/caramenghitung-kebutuhan-pemakaian-pk-ac-sesuai-ruangan/

7. Weather and Climate. (19. 02 2017). Von https://weather-and-climate.com/averagemonthly-Rainfall-Temperature-Sunshine, Surabaya,Indonesia. 